\title{
Effect of cocoa bean origin and conching time on the physicochemical and microstructural properties of Indonesian dark chocolate
}

\author{
Efeito da origem do grão de cacau e do tempo de conchagem \\ nas propriedades físico-químicas e na microestrutura de \\ chocolate amargo da Indonésia
} Kiki Fibrianto1* (i), La Ode Muhammad Fajrul Azhar ${ }^{1}$, Sukrisno Widyotomo²,
Harijono Harijono ${ }^{1}$

${ }^{1}$ Universitas Brawijaya, Brawijaya Senso-Gastronomy Center, Faculty of Agricultural Technology, Malang Indonesia

${ }^{2}$ Indonesian Coffee and Cocoa Research Institute, Post-Harvest Technology, Jember - Indonesia

${ }^{*}$ Corresponding Author: Kiki Fibrianto, Universitas Brawijaya, Brawijaya Senso-Gastronomy Center, Faculty of Agricultural Technology, Veteran Street, 65145, Malang - Indonesia, e-mail: kiki.fibrianto@ub.ac.id

Cite as: Fibrianto, K., Azhar, L. O. M. F., Widyotomo, S., \& Harijono, H. (2021). Effect of cocoa bean origin and conching time on the physicochemical and microstructural properties of Indonesian dark chocolate. Brazilian Journal of Food Technology, 24, e2019249. https://doi.org/10.1590/1981-6723.24919

\begin{abstract}
Indonesian cocoa is cheaper and considered second grade compared with most other cocoa. However, the domestic chocolate industry is not well-developed due to significantly low consumption. To cope with these issues, product innovation through technical process improvement is required to stimulate the domestic chocolate industry. This study aimed to investigate the effect of cocoa bean origin and conching time on the physicochemical (water content, texture, color, crude fat content, and melting enthalpy) and microstructural properties of chocolate. The experiment was conducted under a completely randomized factorial design consisting of two factors: cocoa bean origin $(100 \%$ fermented cocoa beans from Jember, 100\% fermented cocoa beans from Southeast Sulawesi, 50\% fermented cocoa beans from Jember $+50 \%$ non-fermented cocoa beans from Southeast Sulawesi, and $50 \%$ fermented cocoa beans from Southeast Sulawesi $+50 \%$ non-fermented cocoa beans from Southeast Sulawesi) and conching time $(4,6$ and $8 \mathrm{~h}$ ). The results showed that cocoa bean origin significantly affected the hardness, gumminess and color of chocolate, including the redness and yellowness level, whereas conching time affected water content, hardness, cohesiveness, elasticity, and crude fat content. Differential scanning calorimetry (DSC) analysis showed that the treatment with $100 \%$ fermented cocoa beans from Jember presented higher values of $T_{\text {onset }} \Delta H_{\text {melt }}$ and area compared with those of the treatment with 100\% fermented cocoa beans from Southeast Sulawesi, which presented higher values of $T_{\text {peak }}$ and $T_{\text {end. }}$ Scanning Electron Microscopy (SEM) analysis showed a distribution of solid and dense particles with crystal interaction with chocolate structures.
\end{abstract}

Keywords: cocoa; chocolate; conching; texture; melting properties; microstructure. 


\section{Resumo}

O cacau da Indonésia é mais barato e geralmente considerado de segunda qualidade. No entanto, a indústria do chocolate não está bem desenvolvida em razão do consumo interno significativamente baixo. Para lidar com essas questões, a inovação de produtos por meio da melhoria de processos técnicos é necessária para estimular a indústria de chocolate na Indonésia. O objetivo desta pesquisa foi investigar o efeito da origem da amêndoa do grão de cacau e do tempo de conchagem nas propriedades físico-químicas (teor de umidade, textura, cor e gordura total, entalpia de fusão) e na microestrutura do chocolate. O experimento foi conduzido usando um delineamento de blocos inteiramente casualizados com planejamento fatorial, consistindo em dois fatores: origem do grão de cacau (100\% de grãos fermentados de cacau de Jember, $100 \%$ de grãos fermentados de cacau do sudeste de Sulawesi, $50 \%$ de grãos fermentados de cacau de Jember + $50 \%$ de grãos não fermentados de cacau do sudeste de Sulawesi e $50 \%$ de grãos fermentados de cacau do sudeste de Sulawesi $+50 \%$ de grãos não fermentados de cacau do sudeste de Sulawesi) e tempo de conchagem (4, 6 e 8 horas). Os resultados mostraram que a origem do grão de cacau afetou significativamente a dureza, a gomosidade e a cor, incluindo o nível de vermelhidão e amarelecimento, enquanto o tempo de conchagem afetou o teor de umidade, dureza, coesividade, elasticidade e gordura total. Os resultados de Calorimetria de Varredura Diferencial (DSC) mostraram que o chocolate com $100 \%$ de grãos fermentados de cacau de Jember tem valor de $\mathrm{T}_{\text {onset }} \Delta \mathrm{H}_{\text {melt }}$ e a área superiores ao chocolate com $100 \%$ de grãos fermentados de cacau de sudeste de Sulawesi, enquanto o chocolate com $100 \%$ de grãos fermentados de cacau do sudeste de Sulawesi apresentou valores maiores de $T_{\text {peak }}$ and $T_{\text {end. }}$. A Microscopia Eletrônica de Varredura (SEM) indicou uma distribuição de partículas sólidas e densas com interação cristalina com estruturas de chocolate.

Palavras-chave: cacau; chocolate; conchagem; textura; propriedades de fusão; microestrutura.

\section{Introduction}

Cocoa (Theobroma cacao L.) is among the three largest commodities in Indonesia (Hatmi \& Rustijarno, 2012). In 2013, the annual world production of cocoa beans was 3.9 million tons; the three largest cocoa bean producers are Côte d'Ivoire (1.445 million tons/year), Ghana (835,000 tons/year), and Indonesia (420,000 tons/year) (International Coffe and Cocoa Organization, 2012). The total area of cocoa plantation in Indonesia in 2013 was 1,852,944 ha, increasing 4.42\% from 1,774,463 ha in 2012. Most of the country's plantations are located on Sulawesi Island: 297,572 ha in Central Sulawesi, 282,071 ha in Southern Sulawesi, 264,954 ha in Southeastern Sulawesi and 180,585 ha in Western Sulawesi (Wahyudi \& Pujiyanto, 2015).

One of the problems the national cocoa industry has been facing is the low price of this commodity. Most of the domestic cocoa production (78.5\%) is exported in the form of dried unprocessed cocoa beans (Rubiyo \& Siswanto, 2012). Farmers prefer selling unprocessed cocoa beans because they want to sell their production more quickly. As a consequence, they receive less money and the national cocoa processing industry becomes less developed (Mulato, 2012). Processing is one way to increase the value of cocoa beans. Chocolate is one of the products made from cocoa beans that can be sold quickly at a higher price.

Chocolate is defined as semi-solid suspensions of fine solid particles from cocoa paste, milk powder, and sugar dispersed in a continuous fat phase (cocoa butter) (Afoakwa et al., 2007). Chocolate is a popular type of treat across the world. People like its taste, texture, and aroma because it has a pleasant effect when consumed (Jati, 2011). Different blending techniques and processing methods result in various types of chocolate for customers to select (Afoakwa et al., 2007).

Chocolate quality depends on structure, technique and ingredients used, since these elements affect its physical characteristics and sensory perception. Processing chocolate involves sophisticated physical and chemical procedures that require technology and different ingredients so that a product with suitable physicochemical attributes and favorable taste can be achieved (Konar, 2013). Different steps (mixing, prerefining, refining, conching, and tempering) and technological parameters adopted during chocolate 
processing influence the characteristics of cocoa and, eventually, those of the end product (Glicerina et al., 2013).

The characteristics of the cocoa beans influence the quality and sensory attributes of chocolate (Lee et al., 2002). Cocoa is the main ingredient of chocolate. The different elevation of cocoa planting determines the characteristics of the cocoa beans (Gu et al., 2013). Environmental factors such as type of soil, elevation, physical and chemical compounds in the soil, and climate are factors that influence the productivity and chemical attributes of cocoa beans (Rubiyo \& Siswanto, 2012). Several previous studies have revealed that location (where cocoa bean is planted) affects the chemical attributes of cocoa beans (Gu et al., 2013; Chaiseri \& Dimick, 1989; Torres-Moreno et al., 2015; Menezes et al., 2016; Acierno et al., 2016). In other words, different cocoa bean origin influences the quality of chocolate as end-product.

Furthermore, cocoa processing also influences the quality of chocolate. One of the cocoa processing steps is conching. Conching is a fundamental step, because it determines particle size, suspension consistency, and viscosity to achieve distinctive texture and sensory perception (Afoakwa et al., 2007). Conching is a mixing step that includes volatilization of fatty acids that will reduce the bitterness and develop distinctive flavor of chocolate (Prawira \& Barringer, 2009). This process develops the soft texture of chocolate, where solid particles such as sugar, cocoa paste, and powdered milk are coated with fat, and this coating enhances the desired soft texture of the chocolate product (Di Mattia et al., 2014). Several research findings revealed the effect of conching towards chocolate quality (Konar, 2013; Prawira \& Barringer, 2009; Misnawi et al., 2006).

This study aimed to describe the effect of cocoa bean origin and conching time on the physicochemical, melting and microstructural properties of chocolate.

\section{Materials and methods}

\subsection{Materials}

Fermented cocoa beans were acquired from the Indonesian Coffee and Cocoa Research Institute offices in Jember and Southeastern Sulawesi while non-fermented cocoa beans were obtained from Southeastern Sulawesi office. Cocoa beans of the Forastero type were used in this study. Milk powder, powdered sugar, vanilla, baking soda, and lecithin were purchased from the Indonesian Coffee and Cocoa Research Institute, Jember, East Java, Indonesia.

\subsection{Chocolate processing}

The ingredients to make dark chocolate and their respective compositions are as follows: cocoa paste (390 g), cocoa butter (310 g), milk powder (115 g), powdered sugar $185 \mathrm{~g})$, baking soda (3 g), vanilla (1 g), and lecithin $(3 \mathrm{~g})$.

The first step in chocolate processing was to mix and grind the milk powder, cocoa paste, cocoa butter, and powdered sugar using a ball mill at $50^{\circ} \mathrm{C}$ for $12 \mathrm{~h}$. After that, these materials were poured into a conching machine. The following conching times were used at $50^{\circ} \mathrm{C}: 4,6$ and $8 \mathrm{~h}$. Lecithin and vanilla were added to the chocolate mixture two hours before the end of conching. The chocolate paste was then tempered. Tempering involved heating the chocolate paste until it reached $50{ }^{\circ} \mathrm{C}$. The temperature was gradually reduced to $29-30{ }^{\circ} \mathrm{C}$. Once the desired temperature had been reached, the molding process began. The chocolate paste was poured into a mold and then stored in a tempering cabinet at $10{ }^{\circ} \mathrm{C}$ for $60 \mathrm{~min}$. The chocolate mixture was removed from the mold and tempered in an air-conditioned room at $25^{\circ} \mathrm{C}$ for one day. The following step involved wrapping the chocolate in aluminum foil and tempering it once again under the aforementioned conditions for seven days. 


\subsection{Experiment design}

The experiment was conducted under a completely randomized factorial design consisting of two factors. The first factor was cocoa bean origin (the raw material), comprising four levels: $100 \%$ fermented cocoa beans from Jember, $100 \%$ fermented cocoa beans from Southeastern Sulawesi, 50\% fermented cocoa beans from Jember $+50 \%$ non-fermented cocoa beans from Southeastern Sulawesi, and 50\% fermented cocoa beans from Southeastern Sulawesi $+50 \%$ non-fermented cocoa beans from Southeastern Sulawesi. The second factor was conching time, which comprised of three levels: 4, 6 and $8 \mathrm{~h}$.

\subsection{Chocolate analysis}

\subsubsection{Water content}

Five grams $(5 \mathrm{~g})$ of sample and $50 \mathrm{ml}$ of toluene solvent were added to a $250 \mathrm{ml}$ Erlenmeyer flask. The sample was placed on a hot plate for $1 \mathrm{~h}$. The water content was calculated using the following equation: water content $(\%)=$ volume of water $/$ ingredient $(\mathrm{g}) \times 100 \%$.

\subsubsection{Texture Profile Analysis (TPA)}

The chocolate sample was analyzed using a CT-3 Texture Analyzer (AMETEK Brookfield, Middleboro, USA). Texture analysis included hardness, cohesiveness, adhesiveness, and gumminess of chocolate. A TA4/1000 probe was used in a 2-cycle compression test with $1000 \mathrm{~g}$ load cell. The sample was analyzed using is a $30 \mathrm{~mm} \times 20 \mathrm{~mm} \times 10 \mathrm{~mm}$ beam size. The criteria of the testing method were as follows: $2 \mathrm{~mm} / \mathrm{s}$ pretest speed, $5 \mathrm{~mm} / \mathrm{s}$ test speed, $5 \mathrm{~mm} / \mathrm{s}$ return speed, $0 \mathrm{~s}$ recovery time, $0 \mathrm{~s}$ hold time, and $6.8 \mathrm{~g}$ trigger load. The chocolate samples were removed from the refrigerator $24 \mathrm{~h}$ prior to the analysis to achieve room temperature.

\subsubsection{Color}

Color of chocolate was determined according to the method described in Jati (2011). A Konica Minolta CR-10 spectrophotometer (Konica Minolta Sensing, Inc., Tokyo, Japan) was used to determine the color of chocolate. Measuring lens were placed on the sample to measure the $L^{*}, a^{*}$ and $b^{*}$ scores. Prior to measurement, the spectrophotometer was calibrated. $L^{*}$, luminance ranging from 0 (black) to 100 (white); and $a^{*}$ (green to red) and $b^{*}$ (blue to yellow).

\subsubsection{Crude fat content}

Crude fat of chocolate was determined according to the method described in Kim et al. (2017). A Soxhlet extractor was used to analyze the percentage of crude fat. $5 \mathrm{~g}$ of sample was placed on filter paper and then covered with fat-free cotton. The sample was inserted into the Soxhlet extractor and then a condenser and a flask were installed on the edges. Hexane solvent was poured into the tool and the sample was refluxed for $5 \mathrm{~h}$. After that, the solvent was distilled and poured into another container. The crude fat content was calculated using the following equation: crude fat content $(\%)=(\mathrm{W} 2-\mathrm{W} 1) / \mathrm{S} \times 100$; where $\mathrm{W} 1$ represents the weight of the flask before extracting the crude fat (g), W2 corresponds the weight of the flask after extracting the crude fat $(\mathrm{g})$, and $\mathrm{S}$ is the sample weight $(\mathrm{g})$.

\subsubsection{Microstructural analysis}

Microstructure of chocolate was determined according to the method described in Furlan et al. (2017a). A TM3000 Tabletop Scanning Electron Microscope (SEM) (Hitachi High Technologies Corporation, Tokyo, Japan) was used for microstructural analysis. The sample was coated with a double-sided adhesive carbon 
sheet and placed on an aluminum sample holder. Micrographs were captured under variable pressure (VP) mode with 1000x, 2000x and 2500x magnification.

\subsubsection{Melting properties analysis}

Melting properties of chocolate were determined according to method by Aidoo et al. (2015). A Differential Scanning Calorimeter (DSC) model DSC 8000 (Perkin Elmer, Waltham, Massachusetts, USA) was used for measuring the melting properties of the sample. $5 \mathrm{mg}$ of the chocolate sample were weighed into the aluminum cups. To run the DSC tool, nitrogen $\left(\mathrm{N}_{2}\right)$ as purge gas was poured at the speed of $20 \mathrm{ml} / \mathrm{min}$ and heated from 15 to $65{ }^{\circ} \mathrm{C}$ with a heating rate of $5{ }^{\circ} \mathrm{C} / \mathrm{min}$. The onset $\left(\mathrm{T}_{\text {onset }}\right)$, peak maximum $\left(\mathrm{T}_{\text {peak }}\right)$, and final $\left(\mathrm{T}_{\text {end }}\right)$ temperatures, the melting enthalpy $\left(\Delta \mathrm{H}_{\text {melt }}\right)$, and the area were automatically calculated after integration of the melting peak using software analysis.

\subsection{Statistical analysis}

The data obtained were subjected to analysis of variance (ANOVA) and comparison of the means was carried out using the Tukey's test. Analyses were performed using the Minitab 16 software.

\section{Results and discussions}

\subsection{Water content}

Water content is an important factor in chocolate, because it is closely related to the texture of chocolate itself (Aidoo et al., 2014). The results showed that cocoa bean origin did not significantly influenced the water content $(p>0.05)$ of chocolate, but conching time did $(p<0.05)$. Longer conching time decreased the water content of the chocolate (Table 1). Conching involves high temperatures $\left(>50^{\circ} \mathrm{C}\right)$, which results in water evaporation (Afoakwa et al., 2007). According to Di Mattia et al. (2014), the objective of conching is to reduce water content, remove unwanted volatile compounds formed during fermentation, and coat the entire surface of solid particles with fat. In this study, conching was an important step, because it reduced water content, increased rheology, and was the most important step for developing chocolate flavor (Fischer et al., 2008). This finding is in line with those of Konar (2013) and Schumacher et al. (2009), who reported that the longer the conching time, the lower the water content of chocolate.

\subsection{Texture Profile Analysis (TPA)}

\subsubsection{Hardness}

Hardness refers to the force necessary to attain a given deformation (Szczesniak, 2002). The ANOVA results showed that there was significant correlation between cocoa bean origin and conching time $(p<0.05)$. The chocolate made with $100 \%$ fermented cocoa beans from Jember presented the highest hardness level and longer conching time resulted in higher hardness levels (Figure 1).

Cocoa bean origin had a significant effect on the hardness level of the chocolate; cocoa beans grown in different plantations resulted in chocolate with different hardness levels. Cocoa butter hardness directly affected the melting rate and melting properties of the chocolate. Cocoa butter containing high concentrations of $\mathrm{POO}$ and $\mathrm{SOO}$ fatty acids ( $p=$ palmitic, $\mathrm{O}=$ oleic, and $\mathrm{S}=$ stearic) resulted in softer cocoa fat properties that showed low hardness level and melting point. On the other hand, cocoa butter with higher concentrations of POS and SOS fatty acids resulted in harder cocoa fat properties and chocolate with higher hardness level (Chaiseri \& Dimick, 1989). 

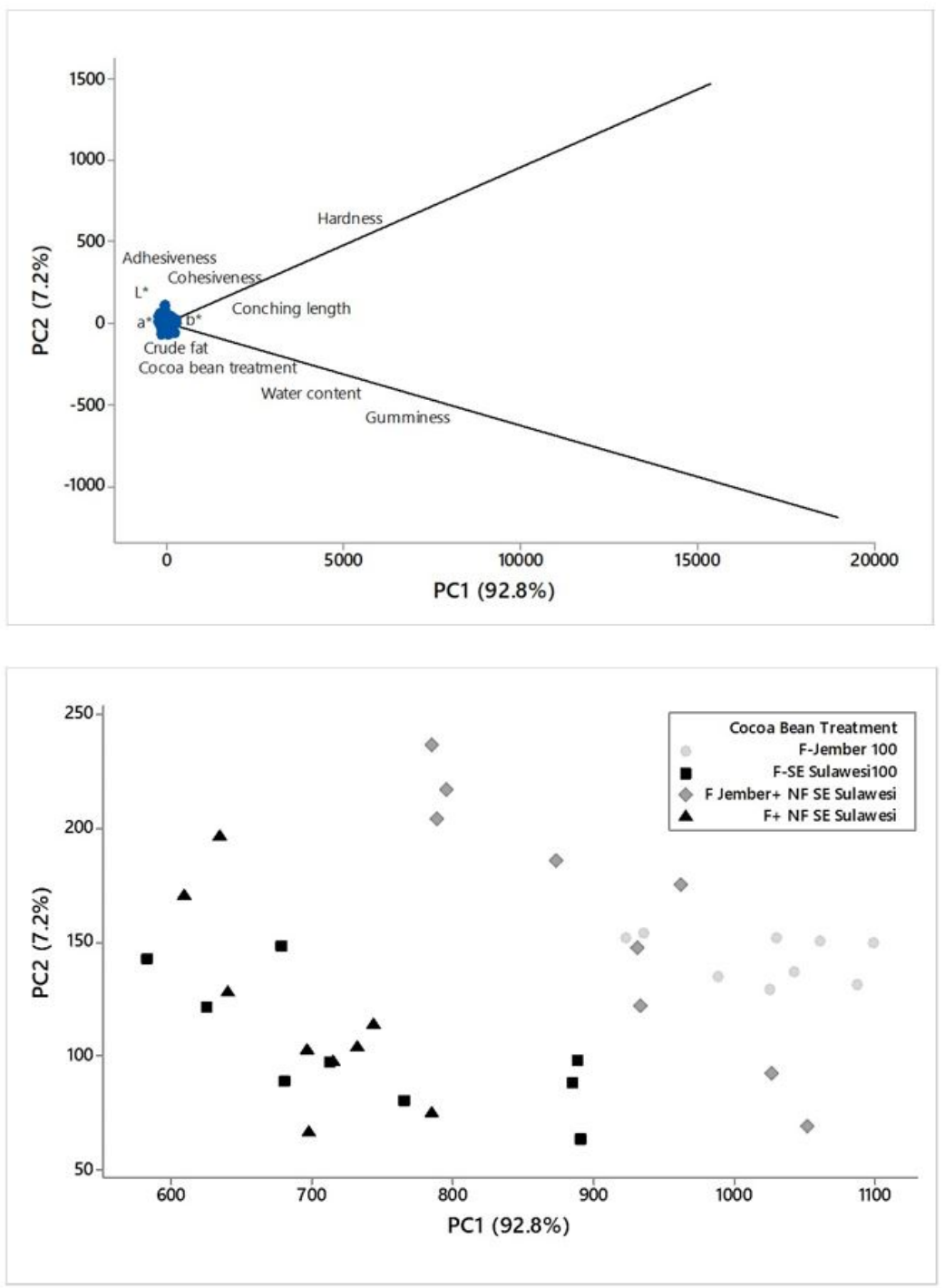

Figure 1. Principal Component Analysis of the effect of cocoa bean origin and conching time for Indonesian dark chocolate. 
Effect of cocoa bean origin and conching time on the physicochemical and microstructural properties of Indonesian dark chocolate

Fibrianto, K. et al.

Table 1. Physicochemical characteristics of Indonesian dark chocolate as affected by different cocoa bean origin and conching time

\begin{tabular}{|c|c|c|c|c|c|c|c|c|c|c|}
\hline $\begin{array}{l}\text { Cocoa } \\
\text { Bean }\end{array}$ & $\begin{array}{l}\text { Conching Time } \\
\text { (Hours) }\end{array}$ & $\begin{array}{c}\text { Water content } \\
(\%)\end{array}$ & Hardness (g) & Cohesiveness & $\begin{array}{c}\text { Adhesiveness } \\
\quad(\mathbf{m J})\end{array}$ & Gumminess (g) & $L^{*}$ & $a^{*}$ & $b^{*}$ & $\begin{array}{c}\text { Crude Fat } \\
\text { Content (\%) }\end{array}$ \\
\hline \multirow{3}{*}{ B1 } & 4 & $0.95 \pm 0.02^{\mathrm{A}}$ & $711.43 \pm 14.33^{c}$ & $0.91 \pm 0.03^{\mathrm{B}}$ & $0.013 \pm 0.01$ & $645.29 \pm 33.27^{\mathrm{aB}}$ & $41.93 \pm 0.40$ & $3.74 \pm 0.03^{\mathrm{a}}$ & $4.67 \pm 0.03^{\mathrm{a}}$ & $39.24 \pm 0.53^{\mathrm{B}}$ \\
\hline & 6 & $0.94 \pm 0.02^{\mathrm{B}}$ & $757.70 \pm 10.62^{\mathrm{ab}}$ & $0.94 \pm 0.02^{\mathrm{B}}$ & $0.020 \pm 0.01$ & $714.65 \pm 9.87^{\mathrm{aB}}$ & $42.01 \pm 0.12$ & $3.72 \pm 0.14^{\mathrm{a}}$ & $4.68 \pm 0.06 \mathrm{a}$ & $39.68 \pm 0.35^{\mathrm{B}}$ \\
\hline & 8 & $0.92 \pm 0.03^{\mathrm{C}}$ & $792.23 \pm 12.98^{\mathrm{a}}$ & $0.96 \pm 0.02^{\mathrm{A}}$ & $0.023 \pm 0.01$ & $751.27 \pm 15.48^{\mathrm{aA}}$ & $42.15 \pm 0.29$ & $3.75 \pm 0.05^{\mathrm{a}}$ & $4.66 \pm 0.24^{\mathrm{a}}$ & $40.62 \pm 0.70^{\mathrm{A}}$ \\
\hline \multirow{3}{*}{ B2 } & 4 & $0.99 \pm 0.04^{\mathrm{A}}$ & $487.60 \pm 9.75^{\mathrm{h}}$ & $0.85 \pm 0.10^{\mathrm{B}}$ & $0.013 \pm 0.01$ & $415.08 \pm 54.86^{\mathrm{cB}}$ & $41.80 \pm 0.40$ & $2.57 \pm 0.19^{d}$ & $4.01 \pm 0.03^{b}$ & $39.70 \pm 0.09^{\mathrm{B}}$ \\
\hline & 6 & $0.90 \pm 0.09^{\mathrm{B}}$ & $536.67 \pm 11.11^{\mathrm{fg}}$ & $0.91 \pm 0.10^{\mathrm{B}}$ & $0.020 \pm 0.01$ & $490.06 \pm 55.29^{\mathrm{cB}}$ & $42.04 \pm 0.07$ & $2.53 \pm 0.03^{\mathrm{d}}$ & $3.96 \pm 0.05^{\mathrm{b}}$ & $39.85 \pm 0.10^{\mathrm{B}}$ \\
\hline & 8 & $0.84 \pm 0.08^{\mathrm{C}}$ & $623.60 \pm 12.94^{\mathrm{e}}$ & $1.02 \pm 0.04^{\mathrm{A}}$ & $0.020 \pm 0.00$ & $637.80 \pm 12.72^{\mathrm{cA}}$ & $42.06 \pm 0.06$ & $2.49 \pm 0.27^{\mathrm{d}}$ & $4.09 \pm 0.08^{b}$ & $40.02 \pm 0.04^{\mathrm{A}}$ \\
\hline \multirow{3}{*}{ B3 } & 4 & $0.97 \pm 0.10^{\mathrm{A}}$ & $668.83 \pm 13.90^{\mathrm{d}}$ & $0.79 \pm 0.14^{\mathrm{B}}$ & $0.013 \pm 0.01$ & $538.27 \pm 95.53^{\mathrm{bB}}$ & $41.95 \pm 0.22$ & $3.47 \pm 0.32^{\mathrm{b}}$ & $4.56 \pm 0.02^{\mathrm{b}}$ & $39.46 \pm 0.40^{\mathrm{B}}$ \\
\hline & 6 & $0.85 \pm 0.06^{\mathrm{B}}$ & $690.53 \pm 11.44^{\mathrm{cd}}$ & $0.80 \pm 0.11^{\mathrm{B}}$ & $0.017 \pm 0.01$ & $550.96 \pm 85.12^{\mathrm{bB}}$ & $41.86 \pm 0.10$ & $3.04 \pm 0.39^{b}$ & $4.46 \pm 0.10^{\mathrm{b}}$ & $39.80 \pm 0.11^{\mathrm{B}}$ \\
\hline & 8 & $0.79 \pm 0.06^{\mathrm{C}}$ & $725.10 \pm 14.25^{\mathrm{bc}}$ & $0.99 \pm 0.12^{\mathrm{A}}$ & $0.020 \pm 0.01$ & $716.76 \pm 70.50^{\mathrm{bA}}$ & $42.05 \pm 0.18$ & $3.21 \pm 0.14^{\mathrm{b}}$ & $4.51 \pm 0.22^{\mathrm{b}}$ & $39.99 \pm 0.12^{\mathrm{A}}$ \\
\hline \multirow{3}{*}{ B4 } & 4 & $0.97 \pm 0.05^{\mathrm{A}}$ & $503.10 \pm 12.63^{\mathrm{gh}}$ & $0.79 \pm 0.25^{\mathrm{B}}$ & $0.013 \pm 0.01$ & $400.38 \pm 15.53^{\mathrm{cB}}$ & $41.78 \pm 0.31$ & $2.74 \pm 0.18^{\mathrm{c}}$ & $4.31 \pm 0.06^{\mathrm{c}}$ & $39.62 \pm 0.35^{\mathrm{B}}$ \\
\hline & 6 & $0.92 \pm 0.02^{\mathrm{B}}$ & $531.87 \pm 17.73^{\mathrm{fg}}$ & $0.92 \pm 0.02^{\mathrm{B}}$ & $0.010 \pm 0.01$ & $476.26 \pm 17.95^{\mathrm{cB}}$ & $42.05 \pm 0.44$ & $2.87 \pm 0.15^{\mathrm{c}}$ & $4.28 \pm 0.12^{\mathrm{c}}$ & $39.71 \pm 0.16^{\mathrm{B}}$ \\
\hline & 8 & $0.84 \pm 0.11^{\mathrm{C}}$ & $553.10 \pm 12.75^{\mathrm{f}}$ & $0.95 \pm 0.06^{\mathrm{A}}$ & $0.013 \pm 0.01$ & $523.71 \pm 19.65^{\mathrm{cA}}$ & $42.09 \pm 0.51$ & $2.75 \pm 0.13^{\mathrm{c}}$ & $4.23 \pm 0.11^{\mathrm{c}}$ & $39.81 \pm 0.22^{\mathrm{A}}$ \\
\hline
\end{tabular}

Five replicates of the color $\left(L^{*}, a^{*}\right.$ and $\left.b^{*}\right)$ experiments were performed. Water content, texture profile analysis (hardness, cohesiveness, adhesiveness, and gumminess), and crude fat experiments were performed in triplicate. All data are reported as mean \pm SD. Different lowercase letters on the same column indicated statistical difference $(p<0.05)$ between cocoa bean origins. Different uppercase letters on the same column indicated statistical difference $(p<0.05)$ between conching times. Letters a-h on the hardness column indicated statistical difference $(p<0.05)$ on the interaction between cocoa bean origin and conching time. B1 $(100 \%$ fermented cocoa beans from Jember), B2 (100\% fermented cocoa beans from Southeastern Sulawesi), B3 (50\% fermented cocoa beans from Jember + 50\% non-fermented cocoa beans from Southeastern Sulawesi), B4 (50\% fermented cocoa beans Southeastern Sulawesi $+50 \%$ non-fermented cocoa beans from Southeastern Sulawesi) 
The cocoa butter, which showed a large amount of stearic and palmitic fatty acids, presented higher hardness level and melting point as a result of the high melting points found in these fatty acids (Chaiseri \& Dimick, 1989).

Differences in hardness level can also be caused by the type of cocoa beans used: fermented or nonfermented. According to Asep et al. (2008), non-fermented cocoa beans contain higher levels of POP and SOS fatty acids than fermented cocoa beans. In addition, non-fermented cocoa beans contain higher levels of POO and SOO fatty acids than fermented beans. Cocoa butter containing high concentration of POO and SOO fatty acids resulted in softer cocoa fat properties that had low hardness level and melting point (Chaiseri \& Dimick, 1989). Longer conching processes increased the hardness level of chocolate. Conching increased the hardness level of chocolate because the particle size was decreasing. Longer conching time resulted in softer chocolate with smaller particle size (Prawira \& Barringer, 2009). Particle size was inversely proportional to the hardness level of chocolate; chocolate with smaller particle size had higher hardness level (Konar, 2013), corroborating the findings of the studies conducted by Do et al. (2007) and Afoakwa et al. (2008b). Smaller particle resulting in increasing hardness level occurred as a result of interaction between chocolate particles. Afoakwa et al. (2009b) reported that chocolate with smaller particle size had larger surface, smaller diameter, and higher inter-particle interaction and contact. When particle size was smaller, crystals were denser and reduced the linear interactions between particles as a result of the longer distances between them; fat then fill the space (Glicerina et al., 2015). Chocolate with larger particle size resulted in weak interactions between particles that, in turn, resulted in lower maximum power to suppress chocolate and low hardness level (Biswas et al., 2017).

\subsubsection{Cohesiveness}

Cohesiveness refers to extent to which a material can be deformed before it ruptures (Szczesniak, 2002). Cohesiveness showed internal force forming a type of food or how cohesively the materials contained in the food interacted. Results of the ANOVA showed that cocoa bean origin did not have any significant effect on chocolate cohesiveness $(p>0.05)$, but the conching time did. Longer conching time resulted in higher cohesiveness level of the chocolate (Table 1).

Cohesiveness of chocolate increased because conching decreased the chocolate particle size. Longer conching processes resulted in smaller particle size, which resulted in increased number of particles, surface area, and interaction between the particle surfaces. A larger particle size may decrease the level of cohesiveness, since particle size was evenly distributed and smaller particles filled the spaces between the larger particles, and these reduced the cohesiveness of the chocolate (Afoakwa et al., 2008d).

\subsubsection{Adhesiveness}

Adhesiveness refers to the work necessary to overcome the attractive forces between the surface of the food and the surface of the other materials with which the food comes in contact (Szczesniak, 2002). Results of the ANOVA showed that cocoa bean origin and conching time did not significantly influence chocolate adhesiveness $(p>0.05) .100 \%$ fermented cocoa beans from Jember and 8 hours conching time presented the highest adhesiveness level.

Adhesiveness had a parallel relationship with chocolate hardness. Chocolate with high hardness level also presented high adhesiveness level. In other words, chocolate would have high adhesiveness level if it had high hardness level. Adhesiveness was inversely proportional to particle size, which means that the smaller the particle, the stickier the chocolate (Afoakwa et al., 2008b). Increased adhesiveness level occurred because conching decreased the particle size. According to Prawira\& Barringer (2009), particle size reduces during the conching process. 


\subsubsection{Gumminess}

Gumminess refers to amount of energy required to disintegrate semi-solid food to a state ready for swallowing (Szczesniak, 2002). Results of the ANOVA indicated that cocoa bean origin and conching time had a significant effect on chocolate gumminess $(p<0.05)$ while interaction did not $(p>0.05) .100 \%$ fermented cocoa beans from Jember and 8-hour conching time presented the highest gumminess rate (Table 1).

Hardness level affected gumminess: the higher the hardness level of chocolate, the higher its gumminess level (Diamantino et al., 2014). Based on the analysis of chocolate hardness, $100 \%$ fermented cocoa beans from Jember had the highest hardness level and, therefore, the highest gumminess level as well.

Chocolate gumminess increased with increasing the conching time. This was expected because the effect of reduced particle size is similar to that of longer conching time on chocolate hardness level. Longer conching decreased the particle size and increased the hardness level of chocolate (Afoakwa et al., 2008b). Smaller particle size increased chocolate hardness. Chocolate gumminess was influenced by its hardness, thus the harder the chocolate, the softer the gumminess (Diamantino et al., 2014). In general, gumminess level was related to hardness, cohesiveness, and elasticity of chocolate (Huang et al., 2005). Chocolate with smaller particle size had wider surface and, as an effect, more frequent inter-particle contact and interaction. Smaller particles became smaller, resulting increased number of particles with wider surface and more frequent contact between their surfaces.

\subsection{Color}

Color is one of the pivotal attributes of a product because it attracts customers (Aidoo et al., 2015). It also influences expectation and acceptance towards the sensory characteristics of a certain food type. Table 1 describes the average color of the chocolate manufactured.

Results of the ANOVA showed that cocoa bean origin and conching time did not have a significant effect on chocolate lightness $(p>0.05)$. These results also showed that conching time did not significantly influence chocolate yellowness and redness $(p>0.05)$, but cocoa bean origin did $(p<0.05)$. Chocolate luminescence level was adapted from the findings of Konar (2013) and Afoakwa et al. (2008c). The analysis showed that chocolate luminescence represented longer conching time and increased with decreasing particle size. Smaller chocolate particle size resulted in shiny chocolate surface with higher luminescence degree; in contrast, larger chocolate particle size had less reflection and resulted in opaque chocolate surface (Misnawi et al., 2006). Chocolate samples with finer particles had wider surface and smaller diameter that tended to reflect more light, as well as lighter surfaces compared with those of chocolate samples with coarser particles (Afoakwa et al., 2009b). Briones et al. (2006) suggested that smoother chocolate surface would produce chocolate with higher luminescence degree.

\subsection{Crude fat content}

Fat is defined as triglycerides that become solid under room temperature. Fat content in food is crude fat and total content of lipids in the actual amount. Result of the ANOVA showed that cocoa bean origin did not significantly influence chocolate crude fat $(p>0.05)$ while conching time did $(p<0.05) .100 \%$ fermented cocoa beans from Jember and 8-hour conching resulted in chocolate with the highest crude fat content (Table 1).

Longer conching time increased crude fat content. Increased crude fat content and conching time were inversely proportional to the water content of chocolate, in which lower crude fat and water contents resulted in chocolate with higher crude fat content, corroborating the findings reported by Kim et al. (2017), who found that chocolate with low water content had high crude fat content. 


\subsection{Microstructure}

Scanning Electron Microscopy (SEM) is a technique used for microstructural analysis of chocolate samples (Delbaere et al., 2016). SEM uses electron beams and is able to describe the morphology of chocolate sample with high magnification (James \& Smith, 2009). Figure 2 describes the results of SEM analysis on the chocolate profile.

Microstructural analysis of the chocolate using SEM showed variation in the crystal network structure, inter-crystal interaction, and particle distribution using 1000x, 2000x and 2500x magnification. Figures $2 \mathrm{~A}$, $2 \mathrm{~B}$ and $2 \mathrm{C}$ show the micrographs of $100 \%$ fermented cocoa beans from Jember with 6-hour conching and Figures 2D, 2E and 2F show the micrographs of $100 \%$ fermented cocoa beans from Southeastern Sulawesi with 6-hour conching. Micrographs of the chocolate revealed an even distribution (particles were close to each other) where the particles were dispersed in the matrix surrounded by voids or pores.

The micrographs of the chocolate made with $100 \%$ fermented cocoa beans from Jember with 6-hour conching showed an evenly distributed crystal web with interaction between crystals and chocolate structure, whereas those of the chocolate made with 100\% fermented cocoa beans from Southern Sulawesi with 6-hour conching also showed an even distribution of smaller crystals in a well-structured web with interaction between the crystals. A large number of small crystals were expected as the preliminary result of nucleation and the growth of crystals resulting from the slow cooling process (Afoakwa et al., 2009a).
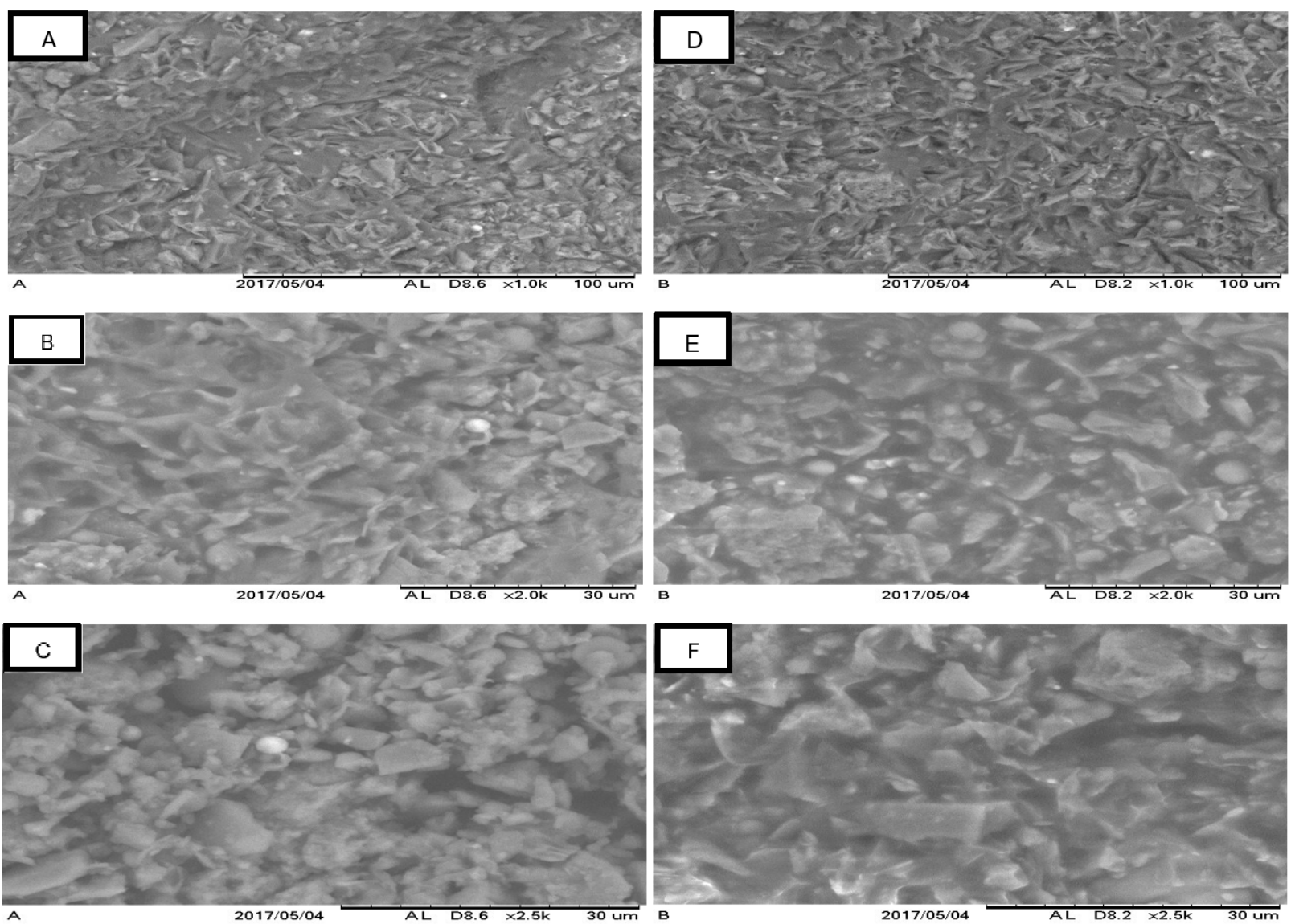

Figure 2. SEM Analysis of Indonesian dark chocolate: (A), (B) and (C) chocolate sample made of $100 \%$ fermented cocoa bean from Jember with 6-hour conching and 1000x, 2000x and 2500x magnification; (D), (E) and (F) chocolate sample made with 100\% fermented cocoa bean from Southeastern Sulawesi with 6-hour conching and 1000x, 2000x and 2500x magnification. 
Morphology of the chocolate samples was relatively homogeneous, with solid particles well mixed with fat in the continuous phase. This may occur during conching, which is a step that allows fat coating of the solid particles (Afoakwa et al., 2009b). The difference in cocoa fat crystallization during the tempering process determines the microstructural formation, which is different from the fat crystals associated with changes in the physical properties of chocolate (Campos et al., 2002). It is important to characterize fat crystals in the chocolate processing industry to determine its physical and sensory properties as a result of the crystallization of cocoa fat and the preparation of structures affecting the mechanical, rheological and melting properties and shelf life of chocolate (Afoakwa et al., 2008a).

\subsection{Melting properties}

Differential Scanning Calorimetry (DSC) was used to analyze the melting properties of the chocolate samples. The thermal parameters involved in the analysis were onset $\left(T_{\text {onset }}\right)$, end $\left(T_{\text {end }}\right)$ and peak $\left(T_{\text {peak }}\right)$ temperatures, melting enthalpy $\left(\Delta \mathrm{H}_{\text {melt }}\right)$, and area. $\mathrm{T}_{\text {onset }}$ refers to the temperature at which specific crystals start melting, $T_{\text {peak }}$ refers to the temperature when the maximum melting point occurs, end $T_{\text {end }}$ refers to the temperature at which the melting process finishes, $\Delta \mathrm{H}_{\text {melt }}$ refers to the energy required to melt a sample, and area refers to the amount of heat absorbed by the sample during the melting process (Afoakwa et al., 2008a). Table 2 describes the analysis of the melting properties of the samples.

Table 2. Effect of cocoa bean origin and conching time on the onset ( $\left.\mathrm{T}_{\text {onset }}\right)$, peak maximum $\left(\mathrm{T}_{\text {peak }}\right)$ and end $\left(\mathrm{T}_{\text {end }}\right)$ temperatures, melting enthalpy $\left(\Delta \mathrm{H}_{\text {melt }}\right)$, and area of Indonesian dark chocolate.

\begin{tabular}{ccccccc}
\hline Cocoa Bean & $\begin{array}{c}\text { Conching time } \\
(\mathbf{h})\end{array}$ & $\begin{array}{c}\mathbf{T}_{\text {onset }} \\
\left({ }^{\circ} \mathbf{C}\right)\end{array}$ & $\begin{array}{c}\mathbf{T}_{\text {peak }} \\
\left({ }^{\circ} \mathbf{C}\right)\end{array}$ & $\begin{array}{c}\mathbf{T}_{\text {end }} \\
\left({ }^{\circ} \mathbf{C}\right)\end{array}$ & $\begin{array}{c}\Delta \mathbf{H}_{\text {melt }} \\
(\mathbf{J} / \mathbf{g})\end{array}$ & $\begin{array}{c}\text { Area } \\
(\mathbf{m J})\end{array}$ \\
\hline $\begin{array}{c}100 \% \text { fermented from Jember } \\
\text { 100\% fermented from Southeastern } \\
\text { Sulawesi }\end{array}$ & 6 & 31.99 & 33.90 & 35.25 & 58.69 & 311.08 \\
\hline
\end{tabular}

The $\mathrm{T}_{\text {peak }}$ of the sample made with $100 \%$ fermented cocoa beans from Jember with 6-hour conching was lower than that of the sample made with 100\% fermented cocoa beans from Southeastern Sulawesi with 6-hour conching, 33.90 and $34.41{ }^{\circ} \mathrm{C}$, respectively. The $\mathrm{T}_{\text {end }}$ of the sample made with $100 \%$ fermented cocoa beans from Southeastern Sulawesi with 6-hour conching was higher than that the sample made with $100 \%$ fermented cocoa beans from Jember with 6-hour conching, 35.73 and $35.25^{\circ} \mathrm{C}$, respectively. The $\mathrm{T}_{\text {peak }}$ of the sample made with $100 \%$ fermented cocoa beans from Jember with 6-hour conching was $33.90^{\circ} \mathrm{C}$ and that of the sample made with $100 \%$ fermented cocoa beans from Southeastern Sulawesi with 6-hour conching was $34.41{ }^{\circ} \mathrm{C}$, showing that the chocolate sample may be in the form of crystal V or Beta 2. Crystal V was crystallized cocoa fat with melting temperature between 32 and $34{ }^{\circ} \mathrm{C}$ (Afoakwa et al., 2008c). Crystal V is the most stable crystallized cocoa fat, and was developed through good tempering (Shah et al., 2010). Crystal $\mathrm{V}$ is a preferable type of crystal because it produces better flavor (Furlan et al., 2017b). Well tempered chocolate developed polymorph V, making it shiny, easy to break, contracting, and resistant to bloom formation during product storage. The $\mathrm{T}_{\text {end }}$ value gives an idea about the melting point and can be used to measure polymorphic status.

DSC analysis showed that the sample made with $100 \%$ fermented cocoa beans from Jember with 6-hour conching had higher $\Delta \mathrm{H}_{\text {melt }}$ compared with that of the sample made with $100 \%$ fermented cocoa beans from Southeastern Sulawesi with 6-hour conching, 58.14 and $56.54 \mathrm{~J} / \mathrm{g}$, respectively. The higher $\Delta \mathrm{H}_{\text {melt }}$ showed that the first sample had greater consistency than the second one. The higher $\Delta \mathrm{H}_{\text {melt }}$ was associated with consistent structure; a more consistent structure requires more energy to melt the fat perfectly (Afoakwa et al., 2009a). The sample made with 100\% fermented cocoa beans from Jember with 6-hour conching was more consistent due to interaction between the particles and the microstructural property of the 
chocolate (Aidoo et al., 2015). Chocolate with high consistency presents solid structure, smaller particle size that fills the voids between the particles and high inter-particle interaction (Furlan et al., 2017b). Evidence of this was that the sample made with $100 \%$ fermented cocoa beans from Jember with 6-hour conching had high $\mathrm{T}_{\text {onset }}$ and $\Delta \mathrm{H}_{\text {melt }}$ values. The chocolate sample that required higher energy to melt had higher heat resistance and longer shelf life, because it presented better stability against fluctuating temperature during storing, which can prevent melting as well as development of fat bloom on the chocolate surface (Furlan et al., 2017a).

DSC analysis showed that the sample made with $100 \%$ fermented cocoa beans from Jember with 6-hour conching had larger area compared with that of the sample made with $100 \%$ fermented cocoa beans from Southeastern Sulawesi with 6-hour conching, 311.08 and $282.92 \mathrm{~mJ}$, respectively. The area refers to the amount of heat the sample absorbed during the melting process (Afoakwa et al., 2008a).

\section{Conclusion}

The study results showed that cocoa bean origin and conching time significantly affected the physicochemical and microstructural properties of Indonesian dark chocolate. This study suggests that the hardness, gumminess, yellowness and redness of dark chocolate from Jember are significantly higher than those of chocolate from Southeastern Sulawesi. DSC analyses showed that dark chocolate from Jember has higher melting point and melting enthalpy tend that from Southeastern Sulawesi. Meanwhile, considering the conching times of 4, 6 and $8 \mathrm{~h}$, moisture content decreases and crude fat content and all textural parameters increase with increasing conching time. The micrographs of chocolate made with $100 \%$ fermented cocoa beans from Jember with 6-hour conching and chocolate made with $100 \%$ fermented cocoa beans from Southeastern Sulawesi with 6-hour conching showed evenly distributed crystal webs with interaction between crystals and chocolate structure.

\section{References}

Acierno, V., Yener, S., Alewijn, M., Biasioli, F., \& Van Ruth, S. (2016). Factors contributing to the variation in the volatile composition of chocolate: botanical and geographical origins of the cocoa beans, and brand-related formulation and processing. Food Research International, 84, 86-95. http://dx.doi.org/10.1016/j.foodres.2016.03.022

Afoakwa, E. O., Paterson, A., \& Fowler, M. (2007). Factor influencing rheological and textural qualities in chocolate - a review. Trends in Food Science \& Technology, 18(6), 290-298. http://dx.doi.org/10.1016/j.tifs.2007.02.002

Afoakwa, E. O., Paterson, A., Fowler, M., \& Vieira, J. (2008a). Characterization of melting properties in dark chocolate from varying particle size distribution and composition using differential scanning calorimetry. Food Research International, 41(7), 751-757. http://dx.doi.org/10.1016/j.foodres.2008.05.009

Afoakwa, E. O., Paterson, A., Fowler, M., \& Vieira, J. (2008b). Effects of tempering and fat crystallisation behaviour on microstructure, mechanical properties and appearance in dark chocolate systems. Journal of Food Engineering, 89(2), 128-136. http://dx.doi.org/10.1016/j.jfoodeng.2008.04.021

Afoakwa, E. O., Paterson, A., Fowler, M., \& Vieira, J. (2008c). Modelling tempering behaviour of dark chocolates from varying particle size distribution and fat content using response surface methodology. Innovative Food Science \& Emerging Technologies, 9(4), 527-533. http://dx.doi.org/10.1016/j.ifset.2008.02.002

Afoakwa, E. O., Paterson, A., Fowler, M., \& Vieira, J. (2008d). Particle size distribution and compositional effects on textural properties and appearance of dark chocolates. Journal of Food Engineering, 87(2), 181-190. http://dx.doi.org/10.1016/j.jfoodeng.2007.11.025

Afoakwa, E. O., Paterson, A., Fowler, M., \& Vieira, J. (2009a). Influence of tempering and fat crystallization behaviours on microstructural and melting properties in dark chocolate systems. Food Research International, 42(1), 200-209. http://doi: 10.1016/j.foodres.2008.10.007

Afoakwa, E. O., Paterson, A., Fowler, M., \& Vieira, J. (2009b). Microstructure and mechanical properties related to particle size distribution and composition in dark chocolate. Journal of Food Science and Technology. 44(1), 111-119. http://doi: 10.1111/j.1365-2621.2007.01677.x

Aidoo, R. P., Afoakwa, E. O., \& Dewettinck, K. (2015). Rheological properties, melting behavior and physical quality characteristics of sugar-free chocolates processed using inulin/polydextrosa bulking mixtures sweetened with stevia and thaumatin extracts. Lebensmittel-Wissenschaft + Technologie, 62(1), 592-597. http://dx.doi.org/10.1016/j.Iwt.2014.08.043 
Aidoo, R. P., Afoakwa, E. O., Dewettnick, K. (2014). Optimization of inulin and polydextrose mixtures as sucrose replacers during sugar-free manufactures - Rheological, microstructure and physical quality characteristics. Journal Food Engineering, 126, 35-42. http://dx.doi.org/10.1016/j.jfoodeng.2013.10.036

Asep, E. K., Jinap, S., Tan, T. J., Russly, A. R., Harcharan, S., \& Nazimah, S. A. H. (2008). The effects of particle size, fermentation and roasting of cocoa nibs on supercritical fluid extraction of cocoa butter. Journal of Food Engineering, 85, 450458.

Biswas, N., Cheow, Y. L., Tan, C. P., Siow, L. F. (2017). Physical, rheological and sensorial properties and bloom formation of dark chocolate made with cocoa butter substitute (CBS). LWT - Food Science and Technology, 82, 420-428. https://doi.org/10.1016/j.Iwt.2017.04.039

Briones, V., Aguilera, M. J., \& Brown, C. (2006). Effect of surface topography on color and gloss of chocolate samples. Journal of Food Engineering, 77(4), 776-783. http://dx.doi.org/10.1016/j.jfoodeng.2005.08.004

Campos, R., Narine, S. S., \& Marangoni, A. G. (2002). Effect of cooling rate on the structure and mechanical properties milk fat and lard. Food Research International, 35(10), 971-981. http://dx.doi.org/10.1016/S0963-9969(02)00159-X

Chaiseri, S., \& Dimick, P. (1989). Lipid and hardness characteristics of cocoa butter from different geographic regions. Journal of the American Oil Chemists' Society, 66(11), 1771-1776. http://dx.doi.org/10.1007/BF02660745

Delbaere, C., Van de Walle, D., Depypere, F., Gellynck, X., \& Dewettinck, K. (2016). Relationship between chocolate microstructure, oil migration and fat bloom in filled chocolates. European Journal of Lipid Science and Technology, 118(12), 1800-1826. http://dx.doi.org/10.1002/ejlt.201600164

Di Mattia, C., Martuscelli, M., Sacchetti, G., Beheydt, B., Mastrocola, D., \& Pittia, P. (2014). Effect of different conching processes on procyanidin content and antioxidant properties of chocolate. Food Research International, 63(Pt C), 367-372. http://dx.doi.org/10.1016/j.foodres.2014.04.009

Diamantino, V. R., Beraldo, F. A., Sunakozawa, T. N., \& Penna, L. B. (2014). Effect of octenyl succinylated waxy starch as a fat mimetic on texture, microstructure and physicochemical properties of Minas fresh cheese. Lebensmittel-Wissenschaft + Technologie, 56(2), 356-362. http://dx.doi.org/10.1016/j.Iwt.2013.12.001

Do, T. A. L., Hargreaves, J. M., Wolf, B., Hort, J., \& Mitchell, J. R. (2007). Impact of particle size distribution on rheological and textural properties of chocolate models with reduced fat content. Journal of Food Science, 72(9), E541-E552. PMid:18034724. http://dx.doi.org/10.1111/j.1750-3841.2007.00572.x

Fischer, A., Abubaker, T., Hasselbarth, A., \& Ullrich, F. (2008). Understanding the impact of conching on chocolate flavor using a combination of instrumental flavor analysis and tasting techniques. In Proceedings of the 12th Weuman Symposium. Expression of Multidisciplinary Flavour Science (pp. 309-312). Interlaken: Institute of Chemistry and Biological Chemistry, Zurich University of Applied Sciences .

Furlan, L. T. R., Baraco, Y., Lecot, J., Zaritzky, N., Campderros, M. E. (2017a). Effect of sweetener combination and storage temperature on physicochemical properties of sucrose free white chocolate. Food Chemistry, 229, 610-620. http://dx.doi.org/10.1016/j.foodchem.2017.03.002

Furlan, L. T. R., Baraco, Y., Lecot, J., Zaritzky, N., Campderros, M. E. (2017b). Influence of hydrogenated oil as cocoa butter replacers in the development of sugar-free chocolates: use of inulin as stabilizing agent. Food Chemistry, 217, 637-647. http://dx.doi.org/10.1016/j.foodchem.2016.09.054

Glicerina V., Balestra, F., Rossa, M. D., Romani, S. (2015). Effect of manufacturing process on the microstructural and rheological properties of milk chocolate. Journal of Food Engineering, 145, 45-50. https://doi.org/10.1016/j.foodeng.2014.06.039

Glicerina, V., Balestra, F., Rossa, M. D., \& Romani, S. (2013). The influence of process steps on microstructural, rheological and thermal properties of dark chocolate. Journal on Processing and Energy in Agriculture, 17(2), 59-63.

Gu, F., Tan, L., Wu, H., Fang, Y., Xu, F., Chu, Z., \& Wang, Q. (2013). Comparison of cocoa beans from China, Indonesia and Papua New Guinea. Foods, 2(2), 183-197. PMid:28239108. http://dx.doi.org/10.3390/foods2020183

Hatmi, R. U., \& Rustijarno, S. (2012). Teknologi pengolahan biji kakao menuju SNI biji kakao 01-2323-2008 (pp. 1-30).

Yogyakarta: BPTP Yogyakarta.

Huang, S. C., Shiau, C. Y., Liu, T. E., Chu, C. L., \& Hwang, D. F. (2005). Effects of rice bran on sensory and physico-chemical properties of emulsified pork meatballs. Meat Science, 70(4), 613-619. PMid:22063887.

http://dx.doi.org/10.1016/j.meatsci.2005.02.009

International Coffe and Cocoa Organization - ICCO. (2012). The World Cocoa Economy: Past and Present. Abidjan: International Coffe and Cocoa Organization.

James, B. J., \& Smith, B. G. (2009). Surface structure and composition of fresh and bloomed chocolate analysed using X-ray photoelectron spectroscopy, cryo-scanning electron microscopy and environmental scanning electron microscopy. Lebensmitte/Wissenschaft + Technologie, 42(5), 929-937. http://dx.doi.org/10.1016/j.Iwt.2008.12.003

Jati, M. (2011). Effects of fructose and tapioca flour on physical and sensory properties of chocolate bar. Pelita Perkebunan, 27(3), 216-229.

Kim, Y.J., Kang, S., Kim, D. H., Kim, Y. J., Kim, W. R., Kim, Y. M. (2017). Calorie reduction of chocolate ganache through substitution of whipped cream. Journal of Ethnic Foods, 4(1), 51-57. http://dx.doi.org/10.1016/j.jef.2017.02.002

Konar, N. (2013). Influence of conching temperature and some bulk sweeteners on physical and rheological properties of prebiotic milk chocolate containing inulin. European Food Research and Technology, 236(1), 135-143. http://dx.doi.org/10.1007/s00217-012-1873-x 
Effect of cocoa bean origin and conching time on the physicochemical and microstructural properties of Indonesian dark chocolate Fibrianto, K. et al.

Lee, S., Heuberger, M., Rousset, P., \& Spencer, N. D. (2002). Chocolate a sliding interface. Journal of Food Science, 67(7), 2712-2716. http://doi.10.1111/j.1365-2621.2002.tb08803.x

Menezes, A. G. T., Batista, N. N., Ramos, C. L., De Andre E Silva, A. R., Efraim, P., Pinheiro, A. C. M., Schwan, R. F. (2016) Investigation of chocolate produced from four different Brazilian varieties of cocoa (Theobroma cacao) inoculated with Saccharomyces cerivisiae. Food Research International, 81, 83-90. http://dx.doi.org/10.1016/j.foodres.2015.12.036

Misnawi, S., Selamat, J., Wahyudi, T., \& Putriani, N. (2006). Effects of alkali concentration and conching temperature on flavour, hardness and colour of chocolate. Pelita Perkebunan, 22(2), 119-135.

Mulato, S. (2012). Pengembangan teknologi pascapanen pendukung upaya peningkatan mutu kakao. Jember: Indonesian Coffe and Cocoa Research Institute.

Prawira, M., \& Barringer, S. A. (2009). Effects of conching time and ingredients on preference of milk chocolate. Journal of Food and Preservation, 33(5), 571-589. http://dx.doi.org/10.1111/j.1745-4549.2008.00272.x

Rubiyo, R., \& Siswanto, S. (2012). The enhancement and development cocoa (Theobroma cacao L.) in Indonesia di Indonesia. Buletin RISTRI, 3(1), 33-48.

Schumacher, A. B., Brandelli, A., Schumacher, E. W., Macedo, F. C., Pieta, L., Klug, T. V., \& De Jong, E. V. (2009) Development and evaluation of a laboratory scale conch for chocolate production. International Journal of Food Science and Technology, 44(3), 616-622. http://dx.doi.org/10.1111/j.1365-2621.2008.01877.x

Shah, A. B., Jones, G. P., \& Vasiljevic, T. (2010). Sucrose-free chocolate sweetened with Stevia rebaudiana extract and containing different bulking agents - effects on physicochemical and sensory properties. International Journal of Food Science and Technology, v. 45(7), 1426-1435. http://dx.doi.org/10.1111/j.1365-2621.2010.02283.x

Szczesniak, A. S. (2002). Texture is a sensory property. Food Quality and Preference, 13(4), 215-225. http://dx.doi.org/10.1016/S0950-3293(01)00039-8

Torres-Moreno, M., Torrescasana, E., Salas-Salvado, J., Blanch, C. (2015). Nutritional composition and fatty acids profile in cocoa beans and chocolate with different geographical origin and processing conditions. Food Chemistry, 166, 125-132. http://dx.doi.org/10.1016/j.foodchem.2014.05.141.

Wahyudi, T., \& Pujiyanto, M. (2015). Kakao: Sejarah, Botani, Proses Produksi, Pengolahan dan Perdagangan (pp. 1-18). Yogyakarta: Gadjah Mada University Press. 